\title{
The impact of industrial activities on vector-borne disease transmission
}

Robert T. Jones $^{a *}$, Lucy S. Tusting ${ }^{b}$, Hugh M. P. Smith ${ }^{a}$, Sylvester Segbayac, Michael B. Macdonald ${ }^{d}$, Michael J. Bangs ${ }^{e}$, and James G. Logan ${ }^{\text {a }}$, .

a ARCTEC, London School of Hygiene \& Tropical Medicine, London, United Kingdom

${ }^{\mathrm{b}}$ Big Data Institute, Nuffield Department of Medicine, University of Oxford, United Kingdom

${ }^{c}$ Anglogold Ashanti Malaria Control Limited, Ghana

${ }^{d}$ Consultant, Baltimore, United States

e International SOS, Ltd. Papua Province, Indonesia and Lualaba Province, Democratic Republic of the Congo

${ }^{f}$ Department of Disease Control, London School of Hygiene \& Tropical Medicine, United Kingdom

*Corresponding author

\section{ABSTRACT}

Industrial activities have produced profound changes in the natural environment, including the removal of trees, fragmentation of habitats, and creation of larval breeding sites, that have allowed the vectors of disease to thrive. These may be coupled with significant changes to demographics that can potentially increase contact between pathogens, vectors and people, and see a shift of parasites and susceptible populations between low and high endemic areas. Indeed, where vector-borne diseases and industrial activities meet, large numbers of potentially immunologically naïve people may be exposed to infection and many lack the knowledge and means to protect themselves. Such areas are typically associated with inadequate health care, thus allowing industrial development and production sites to become important foci of transmission. The altered local vector ecologies, and the changes in disease dynamics that they affect, create challenges for under-resourced health care and vector-control systems.

\section{Keywords:}

Industrial activity; mining; malaria; vector-borne disease risk.

\section{Introduction}

Industrial activities have an important role in the history and development of human settlements, and can contribute considerably to the economies of resource-endowed countries. However, mining, logging, oil and gas, and other extractive industries can also impose significant negative health externalities and burdens associated with elevated incidence of vector-borne diseases (Saha et al., 2011; Santos et al., 2009; Andrade et al., 1995). In Colombia, for example, alluvial gold mining using simple tools and other rudimentary methods is traditionally a single-person operation for extracting ore, and is typically associated with low malaria risk, whereas large open-pit mining is associated with a higher malaria incidence (Castellanos et al., 2016). Overall, the Amazon River Basin accounted for 92.5\% of malaria cases in the Americas in 2014 (Pan American Health Organization, 2014), with cases mostly being reported in areas of recent human encroachment, new agricultural settlements, and open-cast mining sites (Tauil, 1986; Camargo et al., 1994; Sanchez et al., 2017; Recht et al., 2017).

The associations between malaria and mining are multi-factoral, and result from (i) environmental changes that affect malaria transmission ecology and epidemiology, (ii) increased human movement 
between malaria transmission zones, and (iii) various direct and indirect economic and demographic factors linked to mining activities (Confalonieri et al., 2014; Bauch et al., 2015; Andrade et al., 1995; Veeken, 1993; Soe et al., 2017). Firstly, mining methods can create ideal aquatic ecological niches for vector anopheline mosquitoes to propagate and survive (Fernando et al., 2016). Mining activities also ensure a greater number of repeated contacts between human reservoirs of disease pathogens and the mosquito vector (Silbergeld et al., 2002). Over time, the unsteady pattern of human migration, and the highly variable ecological changes associated with mining activities, may be replaced by a more organized infrastructure through the process of urbanization and the development of greater community cohesion. At this point, pathogen/vector exposure to humans is reduced, and more stable, low levels of transmission and rates of malaria infection result (de Castro et al., 2006). This outcome is similar to trends seen in agricultural settlements: recently arrived settlers, usually located closer to the deforestation imprints of side roads, may be more exposed to malaria because of their proximity to the forest fringes where larvae are dense, but as deforestation progresses, transmission decreases (Barros and Honório, 2015).

The development of formal industrial activities such as large mine sites has the potential to greatly affect the socioeconomic profile of previously isolated, less populated rural districts (Kitula, 2006; Obiri et al., 2016; Wilson et al., 2015). In addition to an open pit mine and processing plant, an entire infrastructure base may be created that can include an airstrip, multiple access roads, maintenance and administrative facilities, and new residential settlements for the workforce and their families. Moreover, as a result there are direct and indirect ecological, social, economic, and health impacts on the surrounding communities (Knoblauch et al., 2017; Attuquayefio et al., 2017; Jacobi et al., 2011; Richards and VanWey, 2015; Hilson and Laing, 2017; Gibb and O'Leary, 2014; Bauch et al., 2015; Arrifano et al., 2018,).

Examples of primary vectors of malaria include Anopheles darlingi in South America (Hiwat and Bretas, 2011; Ahumada et al., 2016; Pimenta et al., 2015), An. arabiensis, An. funestus, and An. gambiae in Africa (Sinka et al., 2012; Lobo et al., 2015), and An. fluviatilis in south Asia (Sinka et al., 2011; Sahu et al., 2017). The Anopheles dirus complex, An. maculatus group, An. minimus, An. balabacensis, and An. sundaicus complex represent important vectors in the South-East Asia region (Tainchum, et al., 2015; Kwansomboon et al., 2017, Rahman et al., 1997), while some members of the An. punctulatus group are efficient vectors in the southwest Pacific area (Cooper et al., 2009, Beeb et al., 2015). Aedes aegypti and Ae. albopictus, the primary vectors of important arboviruses including dengue, chikungunya, Zika, and yellow fever, are found widely in tropical and sub-tropical regions (Kraemer et al., 2015; Ducheyne et al, 2018, Weetman et al., 2018). In some countries, the distributions of these species overlap with rich mineral deposits of marketable metals (IBRAM, 2012).

Herein, we consider the large resource and extractive industries that contribute significantly to the developing economies in tropical and subtropical areas of the world that also face major challenges with vector-borne diseases. The environmental and demographic impact of these activities on the occurrence and distribution of vector-borne diseases is discussed.

\section{Methods}

A literature search was performed using archives of published biomedical and life sciences journal literature available through PubMed (MEDLINE) and Web of Science. Search terms included: "African 
trypanosomiasis AND industrial activity" OR "African trypanosomiasis AND mining" OR "Chagas AND industrial activity" OR "Chagas AND mining" OR "Chikungunya AND industrial activity" OR "Chikungunya AND mining" OR "Dengue AND industrial activity" OR "Dengue AND mining" OR "Japanese encephalitis AND industrial activity" OR "Japanese encephalitis AND mining" OR "Leishmaniasis AND industrial activity" OR "Leishmaniasis AND mining" OR "Lymphatic filariasis AND industrial activity" OR "Lymphatic filariasis AND industrial activity" OR "Lymphatic filariasis AND mining" OR "Lymphatic filariasis AND mining" OR "Malaria AND industrial activity" OR "Malaria AND mining" OR "Rift Valley fever AND industrial activity" OR "Rift Valley fever AND mining" OR "Sleeping sickness AND industrial activity" OR "Sleeping sickness AND mining" OR "Vector-borne disease AND industrial activity" OR "Vector-borne disease AND mining" OR "Yellow fever AND industrial activity" OR "Yellow fever AND mining" OR "Zika AND industrial activity" OR "Zika AND mining". These searches were made without restrictions on languages or publication dates. Active searches were made in JuneJuly 2017. Additional resources were subsequently accessed to strengthen the narrative and provide contextual information to the findings of the literature search.

\section{Results}

\subsection{Literature search}

The literature search returned 785 potential references. Of these, 164 were selected for further review based on the reference titles, and 31 of these have been cited herein.

\subsection{Impact of industrial activities on malaria transmission}

There is strong evidence for a link between industrial activities and transmission of malaria, and important examples of these associations have sufficient and reliable background (pre-development) disease information to derive an assessment of impact. In Colombia, one third of reported malaria cases are from active mining areas, and undocumented population migration combined with substantial under-reporting and self-treatment in areas with illegal mining activity suggest that official statistics are likely to significantly underestimate the true burden of disease (Castellanos et al., 2016). Furthermore, mining activity plays an important role in the maintenance of focal and regional malaria transmission, and could be an important obstacle to its elimination (Castellanos et al., 2016; Recht et al., 2017). There are mining-related communities living in close proximity to mine sites, and workers in these sites often demonstrate an ignorance of health promotion and disease prevention methods against mosquito vectors, as has been reported in other countries (Knoblauch et al., 2014; Mazigo et al., 2010; Potter et al., 2016). Whilst malaria declined in Colombia from approximately 117,000 cases in 2010 to around 60,000 in 2013, including an overall reduction in malaria cases in most active mining areas, the mining districts of San Martin de Loba, Costa Pacifica Sur and north-eastern parts of Antioquia reported an increase in the Annual Parasite Incidence (API = cases per 1,000 exposed) by more than $50 \%$ over a 5 -year period (Castellanos et al., 2016).

Associations between mining and malaria have also been found in Peru, where transmission in Madre de Dios in the southern Peruvian Amazon basin is unstable, geographically heterogeneous, and strongly associated with illegal gold mining. Health facilities located in areas of intense illegal gold mining reported 30-fold more cases than those in non-mining areas, although adjustments for population size were not possible due to the intense migration in these area (Sanchez et al., 2017). Further north in French Guiana, malaria outbreaks have been reported in soldiers and military police 
returning from illegal gold mining sites in remote rainforest areas (Pommier de Santi et al., 2016a; Pommier de Santi et al., 2016b). Between 1985 and 1996, a statistically significant association was found between the amount of gold extracted and malaria incidence in Mato Grosso, Brazil, i.e. for every increment of $100 \mathrm{~kg}$ of gold extracted, models predict that the API in mining areas increased by 0.31 (Duarte and Fontes, 2002). At present, malaria infections among miners in Brazil constitute approximately $6 \%$ of the country's total cases, $3 \%$ in Colombia, and a remarkable $47 \%$ in Venezuela (Recht et al., 2017).

\subsection{Association of industrial activities with the transmission of other diseases} Industrial activities, often associated with dramatic environmental modifications, deforestation and human migration and movement, are not just linked with malaria but other diseases transmitted by insect vectors, including leishmaniasis in Suriname and Brazil (Dourado et al., 1989; van der Meide et al., 2008). In the state of Pará, Brazil, the forest areas around the Capiranga bauxite mining base in Juruti have shown heavy occurrence of the sand fly vectors capable for transmitting the protozoan agents causing diffuse cutaneous and mucocutaneous leishmaniasis (Garcez et al., 2009). The principal vector of mucocutaneous leishmaniasis, Lutzomyia (Psychodopygus) complexa has daytime feeding habits, an unusual behaviour among Amazonian phlebotomines, which increase the risk of human exposure to infection (Garcez et al., 2009). An array of Leishmania vector-reservoir relationships, which includes up to eight phlebotomine species, has been described in Serra do Navio, a historic mining area in the Guiana Shield of northern Brazil (Almeida de Souza et al., 2017).

In parts of Queensland Australia, gold miners are vulnerable to dengue fever because the immature stages of the primary vector, Ae. aegypti, can be found abundantly in abandoned flooded mine shafts, making adults available for the transmission of disease (Russell et al., 1996; Eisler 2003). By contrast, occupational exposure associations with Rift Valley fever in Africa, transmitted by several mosquito species including Aedes species, are related to livestock and forestry work exclusive of industrial activities (Olaleye et al., 1996; LaBeaud et al., 2015).

Culex quinquefasciatus is prevalent in tropical and sub-tropical areas (Samy et al., 2016), and is identified as the major vector of the filarial nematode, Wuchereria bancrofti, in parts of South America, Africa, and Asia (Brito et al., 1997; Kramer et al., 2008; Chandra et al., 2007). It frequently breeds in drains, ditches, and other peri-domestic habitats that hold water and organic material long enough for the development of larvae to the adult stage (Prakash et al., 1998; Noori et al., 2015). In a district of West Bengal, India, the numbers of $C x$. quinquefasciatus were found to be significantly higher in colliery areas than in non-colliery areas, and were determined to be a major reason for the higher prevalence of bancroftian filariasis in that area (Adhikari and Haldar, 1995). This supported earlier findings of Culex fatigans in undergrounds pits of a coalmine in India (Dutta, 1977). However, whilst the infection rate and infectivity rate were also found to be higher in the colliery areas, other factors such as exposure of the hosts to coal might impact the pathogenesis of the disease (Adhikari and Haldar, 1995).

Culex mosquitoes include competent vectors of West Nile virus (WNV) and St Louis encephalitis in North America, Rift Valley fever in Africa, and Japanese encephalitis in Southeast Asia (Brualt, 2009; Turell, 2009; Sang et al., 2010; Pearce et al., 2018). Studies in the United States have indicated that WNV incidence increases with urbanization and agriculture, which may result from the habitats used 
and commensal nature of two important vector species, $C x$. pipiens, and $C x$. Tarsalis (Kilpatrick, 2011). Consistent with this, mosquitoes collected from tyres along an urbanisation gradient in South America revealed $C x$. quinquefasciatus to be more frequent at the urban end (Cardo et al., 2018). In this context, it is clear how anthropogenic alterations that affect the availability of breeding sites and other features of local ecology can have impacts on communities of insects of medical importance (AbellaMedrano et al., 2015).

\subsection{Environmental changes that affect vector ecology}

Vector-borne diseases are amongst the infectious diseases with the strongest links to land use since vector ecology is closely affected by the environment (Patz et al., 2004; Zahouli et al., 2017; Young et al., 2017; Sheela et al., 2017). Important aspects of a vector population, such as species diversity and population densities, can be governed by environmental parameters (Petrić et al., 2014; Bashar et al., 2016, Betekov et al., 2010; Confalonieri and Neto, 2012). As environmental conditions change, either through slow natural processes or accelerated by human activities, opportunities arise for important changes in species biodiversity and abundance that can influence a shift in the epidemiological dynamics of transmission and disease risk (Eisen et al., 2008; Ferraguti et al., 2016; Chang et al., 1997; Chinery, 1984; Steiger et al., 2016).

For example, a shift in species composition resulting from industrial activity has been reported in north-eastern Amazonia, where the initial construction of roads in forest areas created large tracts of partially shaded, unpolluted water that is a suitable breeding site for An. darlingi, a primary malaria vector. The subsequent clearing of forest and eventual polluting of water sources made these sites less suitable for these mosquitoes, whereas the creation of stagnant pools for agricultural use attracted other vector species (Conn et al., 2002). This example of land use change allowed a species previously of minor importance, An. marajoara, to become the principal malaria vector in Macapá, Amapá state, Brazil.

Sri Lanka has now been declared a malaria-free country (Wijesundere and Ramasamy, 2017), but historically transmission of malaria was reported when conditions were conducive for the breeding of the primary vector, An. culicifacies (Abeyasinghe et al., 2012). This species breeds in clean stagnant or slow moving waters, and typically thrives in the dry zone, where pools of water collect during the rainy season (Amerasinghe, 1999). Larvae were observed in the water-containing shallow hand-dug gem pits in the Elahera area, in the north central part of the country (Yapabandara and Curtis, 2004). The mining sites were expected to be closed following excavation activities, but many licensed pits were left unfilled, and other pits dug without permits. These pits were documented reaching a density of 247-370 per hectare (Yapabandara and Curtis, 2004). In addition to providing a suitable habitat for $A n$. culicifacies, they are also used for the propagation of An. subpictus and An. varuna, and their creation may have also contributed to the emergence of these species as significant malaria vectors. (Yapabandara and Curtis, 2004; Yapabandara, et al., 2001). In the Kaluganga mining area, a dry zone of central Sri Lanka, mosquito larval surveys indicated that water-filled gem pits contributed $60 \%$ of larvae of the three vector species mentioned (Yapabandara and Curtis 2004). These species show variability in their preferences for feeding and resting, so activities that allow them to thrive have potential impacts on the selection of vector control methods (Rawlings and Curtis, 1982; Yapabandara and Curtis, 2004). Subspecies of these vectors have also demonstrated variability in longevity, 
susceptibility to parasite infection, and resistance to insecticides (Surendran et al., 2006; Surendran et al., 2012).

This historical example highlights the important links between industrial activities, mosquitoes, and malaria, and the need to mitigate these effects. Environmental modifications that included the filling of abandoned gem and quarry pits, and spot checks carried out in areas not covered by sentinel site monitoring, were both parts of an integrated vector control programme that led to the elimination of malaria in Sri Lanka, which has experienced no indigenous cases since 2012 (World Health Organization, 2017). Nonetheless, larval sampling from active and abandoned quarry pits from February 2012-June 2013 revealed the presence of An. culicifacies and other competent malaria vectors, suggesting that there is potential for future epidemics.

The biting activities of An. culicifacies, An. subpictus and An. varuna have been reported to be between 18:00-23:00 hours, with peak biting activity between 19:00-20:00 and a small peak in the early morning hours between 03:00-05:00. (Yapabandara and Curtis, 2004). However, different species can show differences in peak biting time depending on location and season. In South America, An. darlingi has been reported with unimodal, bimodal and even trimodal evening biting peaks, and it has been suggested that these behaviours represent an adaptation to anthropophagy (Rosa-Freitas et al, 1992). Consistent with this, An. darlingi activity in the Sifontes region in southern Venezuela has been found to peak during the night (with two minor peaks at 23.00-00.00 and 03.00-04.00), aligning with the night-time activity of gold mine workers (Moreno et al., 2007). Further, there are differences between species with regards to a preference to feed inside or outside human structures, and whether they take blood meals primarily from human or other animal sources. Differences in biting habits, within the same species or amongst several species, have consequences for vector control, as the use of insecticide-treated nets and indoor residual spraying will be less effective against those mosquitoes that display more outdoor and early evening biting activity. Coupled with this, changes in species composition can change the dynamics of disease transmission based on differences in vector competence and capacity to transmit; e.g., some species are more susceptible to propagating malaria parasites, and others are more refractory (Beerntsen et al., 2000). It is, therefore, important to understand the mosaic of different locally-important vectors and their interactions with human populations, and to recognise that changes in land use may lead to changes in species composition and a consequent change in transmission risk (Conn et al., 2002).

Key environmental changes linked to mining that may significantly influence vector-borne disease transmission, positively or negatively, include: (i) creation of larval habitats, (ii) removal of trees (shading), and (iii) fragmentation of habitats, each of which can produce changes in mosquito populations.

\subsubsection{Creation of larval habitats}

The excavation of minerals directly creates open pits to access ore, and other disturbances of surrounding ground to support these activities (e.g., road building, drainage), also create depressions which are liable to fill with rainwater. Other industrial activities, such as construction or creation of borrow pits, can similarly produce human-made aquatic habitats that are permanent or temporary. These can become important larval habitats for some malaria vector species (Conde et al., 2015; Soleimani-Ahmadi et al., 2013; Mereta et al., 2013). Freshly excavated pits, in particular, have been 
found to contain abundant immature An. gambiae s.l. in Ethiopia, and An. culicifacies in South India (Russell and Rao 1942; Kiszewski et al., 2014).

Industrial scale gold mining activities in Niolam (Lihir) Island in Papua New Guinea offer a model for the types of problems associated with human changes to tropical environments (Ebsworth et al., 2001). Before mining activities began, entomological surveys suggested that An. farauti s.I. was the most important vector of malaria and lymphatic filariasis (Wuchereria bancrofti), and largely responsible for the intense, year-round transmission of both diseases on the island; Anopheles punctulatus, on the other hand, was only recorded in small numbers (Bockarie et al., 1994; Ebsworth et al., 2001). The construction of the gold mine, port, processing plant, roads, and worker housing in the area were associated with significant environmental changes and, interestingly, a change in the relative abundance and distribution of the primary malaria vectors. Subsequent entomological surveys revealed that An. punctulatus was widespread and abundant (Bockarie et al., 1994). This is significant as An. punctulatus is regarded a more efficient malaria vector species than members in the An. farauti complex (Beebe et al., 2013). The most common sites for An. punctulatus immature stages were small temporary, sunlit pools, commonly formed along the edges of poorly drained sections of dirt roads. The rarest larval habitats were the more permanent ecotypes such as lake edges and natural wetlands (Ebsworth et al., 2001). A mine-funded, integrated vector control intervention began in 2004 that led to a substantial reduction of both $P$. vivax and $P$. falciparum infections in the mining-impacted areas (Mitjà, et al., 2013).

\subsubsection{Removal of trees}

The removal of trees (thus shading) and disturbed earth movement associated with mining activities allows pools of rainwater to form that are suitable aquatic habitats for certain species of mosquitoes (Silbergeld et al., 2002). The deforestation of primary or secondary forest has been directly associated with increased mosquito population densities and biting in the Peruvian Amazon: Human biting rates measured at sites selected for primary vegetation type and controlled for human presence found that the predominant malaria vector, An. darlingi, had biting densities more than 200 times greater than attack rates in areas that remained predominantly forested (Vittor et al., 2006). Moreover, sampled aquatic sites with immature $A n$. darlingi had an average of $24 \%$ forest cover compared with $41 \%$ for sites without $A n$. darlingi, indicating that deforestation and associated ecologic alterations in this area increased An. darlingi breeding, and by consequence changed the malaria dynamics of the affected region (Vittor et al., 2009). Similarly, a study of villages in the Lower Caura river basin in Venezuela found that the relative abundance of Anopheles mosquitoes was greatest in the village with the least native forest cover (Rubio-Palis et al., 2013).

There is evidence from Brazil that deforestation has coincided with increases in malaria: after adjusting for access to care, health district size, and spatial trends, Olson and co-workers showed that a 4.3\% change in deforestation in Mâncio Lima, Acre State from August 1997 through August 2000 was associated with a $48 \%$ increase of malaria incidence, which the authors linked with the habitat preference of An. darlingi (Olson et al., 2010). Whilst deforestation may increase vector-borne disease transmission by providing the more open, sunlit breeding sites preferred by An. darlingi vectors, as well as some members in the An. gambiae complex in Africa and of the An. punctulatus group in the southwest Pacific (Sinka et al., 2010; Cooper et al., 2002), care must be taken in finding patterns because of the unique settings in which these changes take place, and because each species may 
respond differently. In parts of Southeast Asia for example, deforestation may lead to reductions of An. dirus and An. balabacensis densities because of a loss of the shaded breeding sites preferred by these species (Yasuoka and Levins, 2007).

The effects of habitat alteration on anopheline mosquito distribution, and their impact on disease transmission, can be complex and difficult to predict. Indeed, a systematic review of the relationship between forest cover and malaria failed to find overwhelming evidence supporting a consistent relationship between deforestation and malaria (Tucker Lima et al., 2017). During the construction of the Jirau hydroelectric dam in Porto Velho, Brazil, human landing catch data indicated a decrease in anopheline species diversity and altering species composition during the first stage of annual flooding, after which species diversity returned to levels observed during the pre-flood stage, despite the permanent change to the ecosystem that the dam introduced (Rodrigures et al., 2017). The continual monitoring of vectors during the operational phase of such projects is therefore important for public health.

\subsubsection{Fragmentation of habitats}

Habitat fragmentation alters the composition of host species in an environment, and could have an impact on disease transmission if vectors are released from predator control or if there is a change in the availability of hosts on which to feed (Kruess and Tscharntke, 1994; Patz et al., 2004). For example, smaller fragments of habitat are less able to support top predator species, and this can result in an abundance of their prey species. If these prey species are reservoirs of infectious disease, the habitat fragmentation could impact disease transmission, as has been reported with the fragmentation of North American forests resulting in the increased incidence of cutaneous and visceral leishmaniasis by peri-domesticated sand flies due to an increase in the number of fox reservoirs (Desjeux, 2001). Equally, if some hosts are more efficient reservoirs of disease than others, habitat fragmentation leading to changes in local species diversity could allow for increases or decreases in the chance of vectors becoming infected, as has been described for Lyme disease spirochete infection of ticks: nymphal infection prevalence is dramatically reduced by the presence of hosts of low reservoir competence (Schmidt and Ostfeld, 2001).

In addition to changing the availability of host species, activities that create forest fringe areas can provide favourable breeding conditions (moist soil areas) for sand fly vectors of leishmaniasis (Azevedo et al., 2011; Feliciangeli, 2004) and various species in the leucosphyrus group of malaria vectors that have a strong proclivity for forested and forest-fringe environments (Sallum et al., 2005). In a frontier settlement of Rorainópolis, in the northern Brazilian Amazon, deforestation has created the unique forest fringe ecosystems that have become hotspots for larvae. Sampling of these areas has revealed a positivity rate of over $80 \%$ for An. darlingi larvae, and they are considered highly focal determinants of malaria transmission (Barros and Honório, 2015).

Forest fragmentation can create a distinct community of species that changes along the edge-tointerior gradient: some species increase in abundance, while others decrease (Yahner et al., 1989), and this phenomenon has been observed in mosquito vectors. A reduction in anopheline species diversity has been demonstrated following forest fragmentation resulting from human activities in northern Thailand (Overgaard et al., 2013). If those species that become predominant are competent vectors of disease and have access to suitable hosts (i.e. humans), the environmental changes could 
favour pathogen transmission (Ferraguti, et al., 2016). Unfortunately, there is a lack of empirical studies demonstrating these outcomes.

There is evidence that habitat fragmentation can affect adaptive genetic variation (Fraser et al., 2014), and it can affect non-adaptive variation through reductions in population size or increased population isolation, which are expected to increase the influence of genetic drift, the stochastic change in allele frequencies over time (Johnson and Munshi-South, 2017). Large genic differences have recently been detected in allopatric populations of Ae. aegypti (Dickson et al., 2017), and the form that preferentially feeds on humans, and resides near human population centres, is known to be more efficient in transmitting disease than that which lives in forested habitats (Sylla et al., 2009). There is considerable variation among other populations of Ae. aegypti in their ecology, behaviour and vector capacity (Crawford et al., 2017). An interesting question for the future is whether habitat fragmentation has the potential to ultimately lead to evolutionary change in disease vectors, and their capacity for disease transmission.

\subsection{Economic and demographic changes}

Together with changes in natural habitats, mining is associated with substantial economic and demographic changes that (i) increase contact between pathogens, vectors and humans, (ii) shift parasites and susceptible human populations between low and high endemic areas, (iii) create vulnerable populations experiencing poor living conditions, and (iv) are typically associated with inadequate health care to deal effectively with vector-borne infections (Potter et al., 2015; Silbergeld et al., 2002; Veeken, 1993; Douine et al., 2017; Recht et al., 2017). For example, the construction of roads into and around mining sites allows previously difficult or inaccessible regions to be settled by an influx of people (Kleinschroth and Healey, 2017). Mining and other industrial activities are also accompanied by expansion of more densely populated environments and can involve the increase of foreign as well as large indigenous workforces (Richards and VanWey, 2015; Coderre-Proulx et al., 2016).

\subsubsection{Increased contact between humans and vectors}

Engagement of populations in mining activities can increase occupation-related exposure of humans to disease vectors (Cotter et al., 2013). Occupational exposure to vector-borne diseases was documented as early as the 1850 s during the construction of the Panama Railroad, when an estimated 12,000 workers died due to vector-borne diseases (malaria and yellow fever) from 1850 to 1855 (McCullough, 1977). More recently, an analysis of factors associated with malaria in Juruena, Matto Grosso, Brazil, in 2005 found that infection prevalence was higher in individuals working in mining activities than observed for house workers (Ferreira et al., 2012), indicating that mining activities place workers at greater risk of contracting malaria. In the Americas as a whole, $60 \%$ of malaria cases occurred in men in 2014, and younger men are more at risk of malaria infection, consistent with the period of life in which individuals are exposed to the highest densities of vectors because of their work (Barbieri et al., 2005; Ferreira et al., 2012; Pan American Health Organization, 2014).

\subsubsection{Migration of workers into and out of mining regions}

The migration of workers to mining and other industrial sites is well documented and has important consequences for transmission of diseases of many kinds, including vector-borne and sexuallycontracted diseases. Malaria infection risk can be described along three main axes: (i) vulnerability, 
(ii) exposure, and (iii) access (Guyant et al., 2015). Migrants may be more biologically vulnerable than indigenous populations in malaria endemic areas because of a lack of naturally-acquired immunity developed from previous infections. For instance, in Juruena malaria prevalence in a mining settlement was $56 \%$ greater in individuals coming from non-endemic areas than in those that originated from malaria endemic areas (Ferreira et al., 2012). Indeed, it was the 'transient nonimmune' population during the Pailin gem rush of the 1950 s and $60 \mathrm{~s}$ that was thought to fuel the emergence of chloroquine resistance in Western Cambodia (Verdrager, 1986). Additionally, having lower immunity, migrants from non-endemic areas are particularly vulnerable to malaria because they have little or inadequate knowledge about the disease and its prevention (Wangroongsarb et al., 2011). Furthermore, migrants are less likely to be aware of existing health services than are local or long-term residents. Lastly, migrants may be more exposed when sleeping or working at night in areas suitable for transmission, and may not take bed nets with them when they cross borders (Prothero, 2002; Malaria Consortium, 2013; Peeters Grietens, 2015).

Access to (or lack of) health services and outreach is the third risk element. The lack of administrative registration among the majority of internal migrants in Cambodia resulted in most households (66.7\%) having never received an insecticide bed net from the National Malaria Control Programme (NMCP), and a majority (76.3\%) of internal migrants reporting never having received an bed net from the NMCP in their home province. Access to malaria services is especially difficult for people who are either defined as illegal migrants or working in an illegal trade who may prefer to avoid contact with government services (Singhanetra-Renard, 1993).

One of the consequences of the migratory nature of mine workforces, formal or informal, is the difficulty of disease surveillance for measuring disease burden. Active case detection implemented by the Brazilian government has been credited with a dramatic reduction in malaria incidence in Mato Grosso from 96.1 to 2.7 cases per 1,000 inhabitants from 1992 to 2002 (Ferreira et al., 2012). Case monitoring can be interrupted or complicated by migration and periodic movement of mine workers, i.e., those who may be missed completely or who may be labelled as imported cases elsewhere.

The second mechanism by which migration linked to mining can increase vector-borne disease transmission is the movement of pathogens into non-endemic areas, for instance through migration of workers out of mining regions. In Colombia, mining populations include individuals that have migrated from areas that are not malaria endemic. Those that then travel back to their places of origin pose a serious risk of introducing infections within a naïve population (Castellanos et al., 2016). An infection tracing study found that over 1,000 cases of malaria, occurring as far away as Rio de Janeiro (approximately 1,700 km), could be linked to gold mining activities in the Tapajós region of Pará. The nature of mining as an episodic occupation that often involves regular movement (e.g., work rotations) contributes to dispersal of disease (Silbergeld et al., 2002). In the particular case of drug resistant strains of malaria, it is believed that mefloquine-resistant $P$. falciparum spread from Borai on the ThaiCambodia border to Mae Sot on the Thai-Myanmar border by infected Burmese gem miners returning by bus from the ruby mines of Cambodia (Wongsrichanalai et al., 2001). Concerns have also been raised about the spread of antimalarial drug resistance in the Guiana Shield, where resistance to artemisinin in Suriname has been linked with gold miners travelling from French Guiana (Pommier de Santi et al., 2016c). 


\subsubsection{Urbanisation, inadequate housing and lack of planning}

When large tracts of land are devegetated and extensively modified by human activities, the process of urbanisation is associated with both the importation of non-native species and the creation of favourable habitats suitable for their establishment (McKinney, 2006). The extent to which a niche opportunity arises for vectors may be site- and species-specific, but have important consequences for disease transmission. For example, expanded urbanization might increase malaria transmission in parts of Asia where An. stephensi can thrive in urban environments (Batra et al., 2001), but elsewhere it has been associated with supressed malaria transmission through a reduction in potential Anopheles larval habitats (de Castro et al., 2006), due to water pollution, better drainage and more impervious surfaces, lower individual human exposure to anopheline vectors due to better housing and greater population density in relation to vectors, and generally better access to health care. It is therefore important that our understanding of events at microgeographic scales not be generalized nor transposed to other regions, which have different vectors, hosts, habitats, and urbanization histories. With this caveat in mind, a generalization that has been observed empirically is that wherever urbanization occurs, some species thrive as urban commensals to the extent that they become dependent on urban resources (McKinney, 2006). Such 'urban exploiters' are composed of a small subset of the world's species and are well adapted to intensely modified human environments (McKinney, 2002).

The increase in the urban and semi-urban populations is typically associated with rapid growth in settlements that are poorly planned with insufficient infrastructure bases, including safe water, proper waste/sewage systems, and organised refuse disposal (Neiderud, 2015; Vij, 2012; United Nations Development Programme, 2016). Urban locations in tropical and sub-tropical areas are becoming increasingly important foci for the transmission of dengue, chikungunya and Zika viruses, and potentially for the spread of yellow fever from sylvan environments into built environments, because they provide ideal habitats for Ae. aegypti, a species which thrives in small man-made collections of water such as discarded plastic containers, gutters, tyres and water-storage containers. Similarly, rubbish in the peri-domestic environment provides breeding sites for sand flies, increasing the risk of leishmaniasis, and Culex quinquefasciatus has been found abundantly in newly developed and urbanized areas of Haiti (Samson et al., 2015). The possibility exists that clearing forest vegetation and developing a more urban environment will allow for other diseases to be transmitted (Asante et al., 2011.)

Poor quality housing construction and poverty in mining areas can increase the risk of vector-borne disease for individuals within households. There is evidence to indicate that well-built housing can reduce house entry by malaria vectors and, therefore, exposure to infection. A systematic review of literature and a meta-analysis showed that improved housing was associated with $47 \%$ lower odds of malaria infection and 45-65\% less clinical malaria than traditional housing in sites across Africa, Asia and South America (Tusting et al., 2015). Similarly, a recent analysis of data from 21 countries in subSaharan Africa found that, after adjusting for household wealth, the association between house design and protection from malaria was similar to that of the use of insecticide-treated nets (ITNs) (Tusting et al., 2017). Compared to malaria, there have been fewer studies linking housing quality with other vector-borne diseases, but there is some evidence of an effect on Aedes-borne diseases and leishmaniasis. Meta-analyses have indicated a significant protective effect of window and door screens on dengue transmission (Bowman et al., 2016), and that ITNs were able to reduce the 
incidence of cutaneous leishmaniasis by $77 \%$ (Wilson et al., 2014). However, the efficacy of ITNs in preventing transmission is dependent on several key variables related to vector biology, type of nets and human behaviour.

In the northwest of Zambia, the development of a copper mine was not associated with a significant increase in the prevalence of $P$. falciparum infection in children. Baseline data collected from 483 children under five-years-of-age in both mine-impacted and comparison sentinel sites, before project development, were compared with data collected four years later when the mine had become operational. The study showed that whilst there was a significantly greater malaria prevalence in the follow-up survey, this was observed both in the impacted and comparison sites (Knoblauch et al., 2017). The overall trend of higher infection rates at this site may have been associated with prevailing temperature and precipitation at the time. However, malaria control interventions implemented by the mine project and district health management teams in the impacted areas, including indoor residual spraying, distribution of ITNs, health awareness campaigns, and active case detection, were generally associated with lower odds (risk) of acquiring infection. In particular, the resettlement of families in new housing with closed eaves and window screens was associated with significantly lower infection rates (Knoblauch et al., 2017).

\subsubsection{Accessibility and lack of health infrastructure}

Mining offers a substantial income, and an opportunity for upward mobility, to an estimated 500,000 small-scale miners across the Amazon region (Cremers and de Theije, 2013), and to millions in other parts of the world (World Bank, 2002). Many malaria-infected miners suffer no significant illness (compared to 'non-immune' individuals) and often do not seek or take prescribed antimalarial agents, or self-medicate (Nacher et al., 2013). However, integrated malaria control programmes rely on early detection and appropriate treatment of infections (Shiff, 2002), and there are specific problems associated with limited access to remote mining concessions and the steady increase in drug-resistant Plasmodium species that confound control efforts, such as chloroquine-resistant $P$. vivax in the Brazilian Amazon (de Santana Filho et al., 2007). The more transient alluvial and artisanal gold-mining sites can be important reservoirs of drug-resistant Plasmodia, placing non-miners and surrounding communities, including indigenous residents, farmers, and forest workers, at increased risk of malaria infection (Andrade et al., 1995).

Mining areas are often characterised by remote, poor accessibility, and marginal health infrastructure. For example, there are many areas in the Amazon region where gold mining and agricultural activities support populations that are too small or malaria prevalence too low to warrant a government clinic for providing malaria diagnosis and treatment (Cunha et al., 2001). A study of knowledge, attitudes and behaviours of small-scale mine workers in Suriname found that the main reasons for not seeking malaria tests were related to geographical barriers, including long distance from a health post and excessive travel time required (Duijves and Heemskerk, 2015). These regions may also be extremely remote, and can be transitory settlements, adding to the difficulty establishing and maintaining health facilities. The same situation occurs in many parts of Asia, where multi-lateral funding proposals for the Greater Mekong Subregion recognise the lack of easier access to health services in general and malaria services in particular, with an expressed need to expand microscopy services and the use of malaria rapid diagnostic tests in remote areas of Myanmar and Southern China (World Health Organization, 2010). 
541 Economic and political instability, and an absence or inadequacy of local public and private 542 institutions, can contribute to increased disease burdens, particularly in the relatively low income settings in which industrial operations can operate. For example, in 1961, Venezuela was the first country in Latin America to declare itself malaria free; however, a notable and steady increase in malaria cases has been observed since 2010, reaching 240,613 cases in 2016 (Pan American Health Organization, 2017). The municipality of Domingo Sifontes recorded the highest number of cases in Venezuela due to an expanding epidemic related to a surge in gold exploitation, which, in part, has been driven by a large-scale loss of jobs and a prolonged country-wide economic crisis. The crisis is also responsible for a shortage of medical supplies and for operational failures in the health system that are leaving cases untreated and under-reported. Further, the government's anti-malaria programme has effectively been dismantled, with supplies stolen or diverted to the informal black market (Ebua, 2017). It is clear that the absence of a once-functional health system leads to more people suffering needlessly from vector-borne diseases.

\section{Conclusions}

Environmental changes that result from small and large-scale industrial activities have been shown to create new opportunities for enhancing vector-borne disease transmission. Where environmental changes occur through large scale extraction projects they can be coupled with demographic factors that expose large numbers of people to diseases for which they have no acquired immunity (Recht et al., 2017). Gaining a better understanding of the influence of human activities on vector-borne disease dynamics, and vector ecology and evolution, will help guide future efforts to minimize the potential negative impacts of industrial development (Johnson and Munshi-South, 2017). For example, deployment of ITNs against vectors that historically fed predominantly indoors on humans has in some areas resulted in persisting transmission by residual populations that survive by feeding outdoors, or on other animals, so an appropriate response is to target them with vapour-phase or veterinary insecticides (Killeen et al., 2017). Similarly, there are opportunities to protect people involved in industrial activities through land use planning and the development of suitable homes that reduce contact with and abundance of vector species (Tusting et al., 2016; Kilpatrick, 2011). Where impacts on disease burden have already been felt, it is crucial that strong, evidenced-based collaborations between industry and health sector stakeholders be made to ensure that vulnerable groups are reached with adequate tools for providing disease risk mitigation, diagnosis and treatment.

\section{List of Abbreviations}

575 API, Annual Parasite Incidence

576 ITN, insecticide treated net

577 NMCP, National Malaria Control Programme

\section{Declarations}

580 The authors declare that they have no competing interests. Declarations of interest: none

\section{Funding}

583 This study was funded in part by a grant from TDR, the Special Programme for Research and Training 
Approaches for The Prevention and Control of Malaria and Emerging Arboviral Diseases: The Impact of Industrial Activities on Vector-Borne Disease Transmission.

\section{Authors' contributions}

RTJ, JGL, MBM and MJB were responsible for the initial study concept. All authors contributed to the research and writing of the article, and provided critical review. All authors read and approved the final manuscript.

\section{Acknowledgements}

We would like thank the following for their kind input and advice, and for sharing documents: $\mathrm{Dr}$ Benjamin Rolfe, CEO, Asia Pacific Leaders Malaria Alliance (APLMA); Ochuko Keyamo, Country Manager, Nigeria; GBCHealth; AngloGold Ashanti, AngloGold Ashanti Malaria Control Ltd. We also thank two anonymous reviewers for their valuable comments.

\section{References}

Abella-Medrano, C.A., Ibáñez-Bernal, S., MacGregor-Fors. I., Santiago-Alarcon, D., 2015. Spatiotemporal variation of mosquito diversity (Diptera: Culicidae) at places with different land-use types within a neotropical montane cloud forest matrix. Parasit. Vectors. 8:487.

Abeyasinghe, R.R., Galappaththy, G.N.L., Smith Gueye, C., Kahn, J.G., Feachem, R.G.A., 2012. Malaria control and elimination in Sri Lanka: Documenting progress and success factors in a conflict setting. PLoS One. 7(8): e43162.

Adhikari, P., Haldar, J.P., 1995. Prevalence of bancroftian filariasis in Burdwan district, West Bengal: II. Vector and microfilariae density in colliery and non-colliery areas. J. Commun. Dic. 27(3)181-185.

Ahumada, M.L., Orjuela, L.I., Pareja, P.X., Conde, M., Cabarcas, D.M., Cubillos, E.F.G., Lopez, J.A., Beier, J.C., Herrera, S., Quinones, M.L., 2016. Spatial distributions of Anopheles species in relation to malaria incidence at 70 localities in the highly endemic Northwest and South Pacific coast regions of Colombia. Malar. J. 15(1): 407.

Almeida de Souza, A.A. Rocha Barata, das Graces Soares Silva, M., Nunes Lima, J.A., Lins Jennings, Y.L., Ishikawa, E.A.Y., Prevot, G., Ginouves, M., Silveira, F.T., Shaw, J., dos Santos, T.V., 2017. Natural Leishmania (Viannia) infections of phlebotomines (Diptera: Psychodidae) indicate classical and alternative transmission cycles of American cutaneous leishmaniasis in the Guiana Shield, Brazil. Parasite. 24:13.

Amerasinghe, P.H., Amerasinghe, F.P., Konradsen, F., Fonseka, K.T., Wirtz, R.A., 1999. Malaria vectors in a traditional dry zone village in Sri Lanka. Am. J. Trop. Med. Hyg. 60:421-429.

Andrade, A., Martelli, C., Oliveira, R., Arias, J., Zicker, F., Pang, L., 1995. High prevalence of asymptomatic malaria in gold mining areas in Brazil. Clin. Infect. Dis. 20(2): 475.

Arrifano, G.P.F., Martín-Doimeadios, R.C.R., Jiménez-Moreno, M., Ramírez-Mateos, V., da Silva, N.F.S., Souza-Monteiro, J.R., Augusto-Oliveira, M., Paraense, R.S.O., Macchi, B.M., do Nascimento, J.L.M., 
Crespo-Lopez, M.E., 2018. Large-scale projects in the Amazon and human exposure to mercury: The case-study of the Tucuruí Dam. Ecotoxicol. Environ. Saf. 147:299-305.

Asante, K., Zandoh, C., Dery, D., Brown, C., Adjei, G., Antwi-Dadzie, Y., Adjuik, M., Tchum, K., Dosoo, D., Amenga-Etego, S., Mensah, C., Owusu-Sekyere, K., Anderson, A., Krieger, G., Owusu-Agyei, S., 2011. Malaria epidemiology in the Ahafo area of Ghana. Malar. J. 10: 211.

Attuquayefio, D.K., Owusu, E.H., Ofori, B.Y., 2017. Impact of mining and forest regeneration on small mammal biodiversity in the Western Region of Ghana. Environ. Monit. Assess. 189(5): 237.

Azevedo, P.C.B.., Lopes, G.N., Fonteles, R.S., Vasconcelos, G., Moraes J.L.P., Rebêlo, J.M.M., 2011. The effect of fragmentation on phlebotomine communities (Diptera: Psychodidae) in areas of ombrophilous forest in São Luís, state of Maranhão, Brazil. Neotrop. Entomol. 40(2): 271-277

Barbieri, A., Sawyer, O., Soares-Filho, B. 2005. Population and land use effects on malaria prevalence in the southern Brazilian Amazon. Hum. Ecol. 33(6): 847-874.

Bashar, K., Rahman, S., Nodi, I.J., Howlader, A.J., 2016. Species composition and habitat characterization of mosquito (Diptera: Culicidae) larvae in semi-urban areas of Dhaka, Bangladesh. Pathog Glob Health. 110(2): 48-61.

Batra, C.P., Adak, T., Sharma, V.P., Mittal, P.K., 2001. Impact of urbanization on bionomics of An. culicifacies and An. stephensi in Delhi. Indian J Malariol. 38(3-4): 61-75.

Bauch, S.C., Birkenbach, A.M., Pattanayak, S.K., Sills, E.O., 2015. Public health impacts of ecosystem change in the Brazilian Amazon. Proc. Natl. Acad. Sci. U. S. A. 112(24): 7414-7419

Barros, F.S.M., Honório, N.A., 2015. Deforestation and malaria on the Amazon frontier: Larval clustering of Anopheles darlingi (Diptera: Culicidae) determines focal distribution of malaria. Am. J. Trop. Med. Hyg. 93(5): 939-53.

Beebe, N. W., Russell, T.L., Burkot, T.R., Lobo, N.F., Cooper, R.D., 2013. The systematics and bionomics of malaria vectors in the southwest Pacific. 357-394. In Manguin S. (ed). Anopheles Mosquitoes - New Insights into Malaria Vectors. InTech, Rijeka, Croatia.

Beebe, N.W., Russell, T., Burkot, T.R., Cooper, R.D., 2015. Anopheles punctulatus group: evolution, distribution, and control. Annu. Rev. Entomol. 60:335-50.

Beerntsen, B., James, A., Christensen, B., 2000. Genetics of mosquito vector competence. Microbiol. Mol. Biol. Rev. 64(1): 115-137.

Beketov, M.A., Yurchenko, Y.A., Belevich, O.E., Liess, M., 2010. What environmental factors are important determinants of structure, species richness, and abundance of mosquito assemblages? J. Med. Entomol. 47(2): 129-139. 
Bockarie, M.J., Dagoro, H., Hii, J., 1994. Health impact of a gold mine in Lihir: entomological investigations. 15 p. Available from Lihir Medical Service, P.O. Box 380, New Ireland Province, Papua New Guinea.

Bowman, L., Donegan, S. McCall, P., 2016. Is dengue vector control deficient in effectiveness or evidence?: Systematic review and meta-analysis. PLoS Negl. Trop. Dis. 10(3): e0004551.

Brault, A.C., 2009. Changing patterns of West Nile virus transmission: altered vector competence and host susceptibility. Vet Res. 2009 Mar-Apr; 40(2): 43.

Brito, A.C., Williams, P., Fontes, G., Rocha, E.M., 1997. A comparison of two Brazilian populations of Culex quinquefasciatus (Say, 1823) from endemic and non-endemic areas to infection with Wuchereria bancrofti (Cobbold, 1877). Mem Inst Oswaldo Cruz. 92(1):33-6.

Camargo, L.M., Ferreira, M.U., Krieger, H., De Camargo, E.P., Da Silva, L.P., 1994. Unstable hypoendemic malaria in Rondonia (western Amazon region, Brazil): epidemic outbreaks and workassociated incidence in an agro-industrial rural settlement. Am. J. Trop. Med. Hyg. 51(1):16-25.

Cardo, M.V., Rubio, A., Junges. M.T., Vezzani. D., Carbajo. A.E. 2018. Heterogeneous distribution of Culex pipiens, Culex quinquefasciatus and their hybrids along the urbanisation gradient. Acta Trop. 178:229-235.

Castellanos, A., Chaparro-Narváez, P., Morales-Plaza, C.D., Alzate, A., Padilla, J., Arévalo, M. and Herrera, S., 2016. Malaria in gold-mining areas in Colombia. Mem. Inst. Oswaldo Cruz. 111(1):59-66

Chandra, G., Chatterjee, S.N., Das. S., Sarkar. N., 2007. Lymphatic filariasis in the coastal areas of Digha, West Bengal, India. Trop. Doct. 37(3):136-9.

Chang, M.S., Hii, J., Buttner, P., Mansoon, F., 1997. Changes in abundance and behaviour of vector mosquitoes induced by land use during the development of an oil palm plantation in Sarawak. Trans. Roy. Soc. Trop. Med. Hyg. 91(4): 382-386.

Chinery, W.A., 1984. Effects of ecological changes on the malaria vectors Anopheles funestus and the Anopheles gambiae complex of mosquitoes in Accra, Ghana. J. Trop. Med. Hyg. 87(2): 75-81.

Coderre-Proulx, M., Campbel, B., Mandé, I., 2016. International migrant workers in the mining sector. International Labour Office. Geneva.

Conde, M., Pareja, P.X., Orjuela, L.I., Ahumada, M.L., Durán, S., Jara, J.A., Cañon, B.A., Pérez, P., Beier, J.C., Herrera, S., Quiñones, M.L., 2015. Larval habitat characteristics of the main malaria vectors in the most endemic regions of Colombia: potential implications for larval control. Malar. J. 14: 476.

Confalonieri, U.E.C., Neto, C.C., 2012. Diversity of mosquito vectors (Diptera: Culicidae) in Caxiuanã, Pará, Brazil. Interdisciplinary Perspectives Infect. Dis. 741273. 
Confalonieri, U.E.C., Margonari, C., Quintão, A.F., 2014. Environmental change and the dynamics of parasitic diseases in the Amazon. Acta Tropica. 129: 33-41.

Conn, J., Wilkerson, R., Segura, M., de Souza, R., Schlichting, C., Wirtz, R., and Póvoa, M., 2002. Emergence of a new neotropical malaria vector facilitated by human migration and changes in land use. Am. J. Trop. Med. Hyg. 66(1): 18-22.

Cooper, R.D., Waterson, D.G.E., Frances, S.P., Beebe, N. W., Sweeney, A.W., 2002. Speciation and distribution of the members of the Anopheles punctulatus (Diptera: Culicidae) group in Papua New Guinea. J. Med. Entomolo. 39(1): 16-27

Cooper, R.D., Waterson, D.G., Frances, S.P., Beebe, N.W., Pluess, B., Sweeney, A.W., 2009. Malaria vectors of Papua New Guinea. Int. J. Parasitol. 39(13): 1495-501.

Cotter, C., Sturrock, H.J., Hsiang, M.S., Liu, J., Phillips, A.A., Hwang, J., Gueye, C.S., Fullman, N., Gosling, R.D., Feachem, R.G., 2013. The changing epidemiology of malaria elimination: new strategies for new challenges. Lancet 382: 900-911.

Crawford, J.E., Alves, J.M., Palmer, W.J., Day, J.P., Sylla, M., Ramasamy, R., Surendran, S.N., Black, W.C., Pain, A., Jiggins, F.M., 2017. Population genomics reveals that an anthropophilic population of Aedes aegypti mosquitoes in West Africa recently gave rise to American and Asian populations of this major disease vector. BMC Biol. 15(1):16.

Cremers, L., de Theije, M., 2013. Small-scale gold mining in the Amazon. Amsterdam, CEDLA.

Cunha, M.L., Piovesan-Alves, F., Pang, L.W., 2001. Community-based program for malaria case management in the Brazilian Amazon. Am. J. Trop. Med. Hyg. 65(6): 872 - 876.

de Castro, M.C., Monte-Mór, R.L., Sawyer, D.O. and Singe, B.H., 2006. Malaria risk on the Amazon frontier. Proc .Natl. Acad. Sci. U.S.A. 103(7): 2452-2457.

de Santana Filho, F.S., Arcanjo, A.R., Chehuan, Y.M., Costa, M.R., Martinez-Espinosa, F.E., Vieira, J.L., Barbosa, M. d. G. V., Alecrim, W.D., Alecrim, M. d. G. C., 2007. Chloroquine-resistant Plasmodium vivax, Brazilian Amazon. Emerg. Infect. Dis. 13(7): 1125-1126.

Desjeux, P., 2001. The increase in risk factors for leishmaniasis worldwide. Trans. R. Soc. Trop. Med. Hyg. 95(3): 239-43.

Dickson, L.B., Campbell, C.L., Juneja, P., Jiggins, F.M., Sylla, M., Black, W.C., 2017. Exon-enriched libraries reveal large genic differences between Aedes aegypti from Senegal, West Africa, and populations outside Africa. G3 (Bethesda). 7(2): 571-582

Douine, M., Mosnier, E., Le Hingrat, Q., Charpentier, C., Corlin, F., Hureau, L., Adenis, A., Lazrek, Y., Niemetsky, F., Aucouturier, A.L., Demar, M., Musset, L., Nacher, M., 2017. Illegal gold miners in French Guiana: a neglected population with poor health. BMC Public Health. 18(1): 23. 
Dourado, M., Noronha, C., Alcantara, N., Ichihara, M. and Loureiro, S., 1989. Epidemiology of tegumentary American leishmaniasis and its relations with agriculture and prospecting, in a locality of the State of Bahia, Brazil. Rev. Saude Publica 23(1): 2-8.

Duarte, E.C., Fontes, C.J.F., 2002. Association between reported annual gold mining extraction and incidence of malaria in Mato Grosso-Brazil, 1985-1996. Rev. Soc. Bras. Med. Trop. 35(6): 665-668.

772

Ducheyne, E., Tran Minh, N.N., Haddad, N., Bryssinckx, W., Buliva, E., Simard, F., Malik, M.R., Charlier, J., De Waele, V., Mahmoud, O., Mukhtar, M., Bouattour, A., Hussain, A., Hendrickx, G., Roiz, D. 2018. Current and future distribution of Aedes aegypti and Aedes albopictus (Diptera: Culicidae) in WHO Eastern Mediterranean Region. Int. J. Health Geogr. 17(1):4

Duijves, C.E., Heemskerk, M., 2015. Study on the knowledge, attitudes and practices of malaria and malaria treatment in the small-scale gold mining sector in Suriname, South America. Trop. Med. Int. Health. 20: 365-365.

Dutta, S.N., 1977. Evidence of Culex fatigans mosquito breeding in underground pits of a coalmine in India. Trans. R. Soc. Trop. Med. Hyg. 71(2)180.

Ebsworth, P., Bryan, J., Foley, D., 2001. Ecological distribution of mosquito larvae of the Anopheles punctulatus group on Niolam (Lihir) Island, Papua New Guinea. J. Am. Mosq. Control Assoc. 17(3): 181185.

Ebua, B., 2017. Malaria infections spreading in crisis-ridden Venezuela. www.aljazeera.com/indepth/features/2017/08/malaria-epidemic-spreading-crisis-ridden-venezuela170802072924748.html?utm_source=Global+Health+NOW+Main+List\&utm_campaign=5835c5233cEMAIL_CAMPAIGN_2017_08_15\&utm_medium=email\&utm_term=0_8d0d062dbd-5835c5233c862787.

Eisen, L., Bolling, B.G., Blair, C.D., Beaty, B.J., Moore, C.G., 2008. Mosquito species richness, composition, and abundance along habitat-climate-elevation gradients in the northern Colorado Front Range. J. Med. Entomology. 45(4): 800-811.

Eisler, R., 2003. Health risks of gold miners: a synoptic review. Environ. Geochem. Health 25(3): 325345 .

Feliciangeli, M.D., 2004. Natural breeding places of phlebotomine sandflies. Med. Vet. Entomol. 18(1): 71-80.

Fernando, A.W., Jayakody, S., Wijenayake, H.K., Galappaththy, G.N., Yatawara, M., Harishchandra, J., 2016. Species composition and population dynamics of malaria vectors in three previously ignored aquatic systems in Sri Lanka. Malar. J. 15(1):268. 
Ferraguti, M., Martínez-de la Puente, J., Roiz D., Ruiz, S., Soriguer R., Figuerola, J., 2016. Effects of landscape anthropization on mosquito community composition and abundance. Sci. Rep. 6: 29002.

Ferreira, I.M., Yokoo, E.M. Souza-Santos, R. Galvão, N.D., Atanaka-Santos, M., 2012. Factors associated with the incidence of malaria in settlement areas in the district of Juruena, Mato Grosso state, Brazil. Cien. Saude Colet. 17: 2415-2424.

Frazer, D.J., Debes, P.V., Bernatchez, L., Hutchings, J.A., 2014. Population size, habitat fragmentation, and the nature of adaptive variation in a stream fish. Proc. Biol. Sci. 281(1790): 20140370.

Garcez, L., Soares, D., Chagas, A., de Souza, G., Miranda, J., Fraiha, H., Flöeter-Winter, L., Nunes, H., Zampiere, R., Shaw, J., 2009. Etiology of cutaneous leishmaniasis and anthropophilic vectors in Juruti, Pará State, Brazil. Cad. Saude Publica. 2 25(10): 2291-2295.

Gibb, H., O'Leary, K.G. 2014. Mercury exposure and health impacts among individuals in the artisanal and small-scale gold mining community: a comprehensive review. Environ. Health. Perspect. 122(7): 667-72

Guyant, P., Canavati, S. Chea N., Ly, P. Whittaker, M., Roca-Feltrer, A., Yeung S., 2015. Malaria and the mobile and migrant population in Cambodia: a population movement framework to inform strategies for malaria control and elimination. Malar. J. 14: 252.

Hilson, G., Laing, T. 2017. Guyana gold: A unique resource curse? J. Development Studies. 53(2):229248.

Hiwat, H., Bretas, G. 2011. Ecology of Anopheles darlingi Root with respect to vector importance: a review. Parasit Vectors. 4: 177.

IBRAM, 2012. Information and Analyses on the Brazilian Mineral Economy 7th Edition. Brasília, Brazil.

Jacobi, C.M., do Carmo, F.F., de Campos, I.C., 2011. Soaring Extinction Threats to Endemic Plants in Brazilian Metal-Rich Regions. Ambio. 40(5): 540-543.

Kleinschroth, F., Healey, J.R., 2017. Impacts of logging roads on tropical forests. Biotropica, June.

Killeen, G.F., Marshall, J.M. Kiware, S.S., South, A.B., Tusting, L.S., Chaki, P.P., Govella, N.J., 2017. Measuring, manipulating and exploiting behaviours of adult mosquitoes to optimise malaria vector control impact. BMJ Glob. Health. 2(2): e000212.

Kilpatrick, A.M., 2011. Globalization, land use and the invasion of West Nile virus. Science, 334(6054): 323-327.

Kiszewski, A., Teffera, Z., Wondafrash, M., Ravesi, M., Pollack, R., 2014. Ecological succession and its impact on malaria vectors and their predators in borrow pits in western Ethiopia. J. Vector Ecol. 39(2): 414-423. 
Kitula, A.G.N., 2006. The environmental and socio-economic impacts of mining on local livelihoods in Tanzania: A case study of Geita District. J. Clean. Production 14: 405e414

Knoblauch, A. M., Divall. M. J., Owuor, M., Archer, C., Nduna, K., Ng'uni H., Musunka, G., Pascall, A., Utzinger, J., Winkler, M.S., 2017. Monitoring of selected health indicators in children living in a copper mine development area in Northwestern Zambia. Int. J. Environ. Res. Public Health 14(3): E315.

Knoblauch, A. M., Winkler, M.S., Archer, C., Divall, M.J., Owuor, M., Yapo, R.M., Utzinger, J., 2014. The epidemiology of malaria and anaemia in the Bonikro mining area, central Côte d'Ivoire. Malar. J. 13: 194.

Kraemer, M.U.G., Sinka. M. A. Duda, K.A., Mylne, A.Q., Shearer, F.M., Barker, C.M., Moore, C.G., Carvalho, R.G., Coelho, G.E., Van Bortel, W., Hendrickx, G., Schaffner, F., Elyazar, I.R., Teng, H.J., Brady, O.J., Messina, J.P., Pigott, D.M., Scott, T.W., Smith, D.L., Wint, G.R., Golding, N., Hay, I., 2015. The global distribution of the arbovirus vectors Aedes aegypti and Ae. albopictus. eLife 4: e08347.

Kramer, L.D., Styer, L.M., Ebel, G.D., 2008. A global perspective on the epidemiology of West Nile virus. Ann. Rev. Entomol. 53: 61-81.

873

Kruess, A. Tscharntke, T., 1994. Habitat fragmentation, species loss, and biological control. Science, 264, 1581-1584.

Karunaweera, N.D, Galappaththy, G.N.L., Wirth, D.F., 2014. On the road to eliminate malaria in Sri Lanka: lessons from history, challenges, gaps in knowledge and research needs. Malar. J. 13: 59.

Kwansomboon, N., Chaumeau, V., Kittiphanakun, P., Cerqueira, D., Corbel, V., Chareonviriyaphap, T., 2017. Vector bionomics and malaria transmission along the Thailand-Myanmar border: a baseline entomological survey. J. Vector Ecology. 42(1): 84-93.

Kweka, E.J., Kimaro, E.E., Munga, S. 2016. Effect of deforestation and land use changes on mosquito productivity and development in Western Kenya Highlands: Implication for malaria risk. Front Public Health. 4: 238.

LaBeaud, A., Pfeil S., Muiruri, S., Dahir, S., Sutherland, L., Traylor, Z., Gildengorin, G., Muchiri, E., Morrill. J., Peters, C., Hise, A., Kazura, J., King, C., 2015. Factors associated with severe human Rift Valley fever in Sangailu, Garissa County, Kenya. PLoS Negl. Trop. Dis. 9(3): e0003548.

Loayza, N., Rigolini, J., 2016. The local impact of mining on poverty and inequality: evidence from the commodity boom in Peru. World Development, 84(C): 219-234. Mueller, J.D., Deason, N.A., Hoang, Q.T., Boldt, H.L., Thumloup, J., Stevenson, J., Seyoum, A., Collins, vector behavior and interventions using molecular tools. Sci. Rep. 5: 17952 
Malaria Consortium. 2013. Cambodia Malaria Survey. www.malariaconsortium.org/mediadownloads/624/Cambodia\%20Malaria\%20Survey\%202013.

Prothero, R.M., 2002. Population movements and tropical health. Glob. Change \& Human Health 3(1): 20-32.

905

Mazigo, H.D., Obasy, E.., Mauka, W., Manyiri, P., Zinga, M., Kweka, E.J., Mnyone, L.L., Heukelbach, J., 2010. Knowledge, attitudes, and practices about malaria and its control in rural northwest Tanzania. Mal. Res. Treatment. 794261.

McCullough, D., 1977. Path between the seas: The creation of the Panama Canal 1870 to 1914 . Simon

McKinney, M.L., 2002. Urbanization, biodiversity, and conservation. BioScience, 52(10): 883-890.

McKinney, M.L., 2006. Urbanization as a major cause of biotic homogenization. Biological Conserv. 127:247-260.

Mereta, S.T., Yewhalaw, D., Boets, P., Ahmed, A., Duchateau, L., Speybroeck, N., Vanwambeke, S.O., Legesse, W., De Meester, L., Goethals, P.L., 2013. Physico-chemical and biological characterization of anopheline mosquito larval habitats (Diptera: Culicidae): implications for malaria control. Parasit. Vectors. 6(1): 320. in Lihir Island, Papua New Guinea. Malar. J. 12: 98.

Moreno, J. E., Rubio-Palis, Y. Páez, E. Pérez E., Sánchez, V., 2007. Abundance, biting behaviour and parous rate of anopheline mosquito species in relation to malaria incidence in gold-mining areas of southern Venezuela. Med. Vet. Entomol. 21: 339-349.

Nacher M, Guérin PJ, Demar-Pierre M, Djossou F, Nosten F, Carme B. 2013. Made in Europe: will artemisinin resistance emerge in French Guiana? Malar. J. 12: 152.

Noori, N., Lockaby, B.G., Kalin, L., 2015. Larval development of Culex quinquefasciatus in water with low to moderate pollution levels. J. Vect. Ecol. 40(2): 208-220.

Neiderud, C-J., 2015. How urbanization affects the epidemiology of emerging infectious diseases. Infect Ecol Epidemiol. 5: 10.3402. 160. 
Olaleye, O., Tomori, O., Ladipo M., Schmitz H., 1996. Rift Valley fever in Nigeria: infections in humans. Rev. Sci. Tech. 15(3): 923-935.

Olson, S.H., Gangnon, R., Abbad Silveira, G., Patz, J.A., 2010. Deforestation and malaria in Mâncio Lima County, Brazil. Emerg. Infect. Dis. 16(7): 1108-1115.

Overgaard, H.J., Ekbom, B., Suwonkerd, W., Takagi, M., 2013. Effect of landscape structure on anopheline mosquito density and diversity in northern Thailand: Implications for malaria transmission and control. Landscape Ecol. 18: 605.

953

United Nations Development Programme, 2016. Human development for everyone. New York, United States.

956

Pan American Health Organization, 2014. Report on the situation of malaria in the Americas. Washington D.C.

959

Pan American Health Organization, 2017. Epidemiological Alert. Increase in cases of malaria. Washington, D.C., USA, 26-30 September 2016.

962

Patz, J.A., Daszak, P., Tabor, G.M., Aguirre, A.A., Pearl, M., Epstein, J., Wolfe, N.D., Kilpatrick, A.M., Foufopoulos, J., Molyneux, D., Bradley, D.J.; Working group on land use change and disease emergence. 2004. Unhealthy landscapes: Policy recommendations on land use change and infectious disease emergence. Environ. Health. Perspect. 112(10): 1092-1098.

Pearce, J.C., Learoyd, T.P., Langendorf, B.J., Logan, J.G., 2018. Japanese encephalitis: the vectors, ecology and potential for expansion. J Travel Med. 25(suppl_1):S16-S26

Peeters Grietens, K., Gryseels, C., Dierickx, S., Bannister-Tyrrell, M., Trienekens, S., Uk, S., Phoeuk, P., Suon, S., Set, S., Gerrets, R., Hoibak, S., Muela Ribera, J., Hausmann-Muela, S., Tho, S., Durnez, L., Sluydts, V., d'Alessandro, U., Coosemans M, Erhart A. 2015. Characterizing types of human mobility to inform differential and targeted malaria elimination strategies in northeast Cambodia. Sci. Rep. 5: 1683.

Petrić, D., Bellini, R., Scholte, E.J., Marrama Rakotoarivony, L., Schaffner, F. 2014. Monitoring population and environmental parameters of invasive mosquito species in Europe. Parasit. Vectors. 7:187. F.A.C., Oliveira, G.A., Campos, K.M.M., Martínez Villegas, L., Barnabé Rodrigues, N., Nacif-Pimenta, R., Simões, R.C., Monteiro, W.M., Amino, R., Traub-Cseko, Y.M., Lima, J.B.P., Barbosa, M.G.V., Lacerda, M.V.G., Tadei, W.P., Secundino, N.F.C., 2015. An overview of malaria transmission from the perspective of Amazon Anopheles vectors. Mem. Inst. Oswaldo Cruz. 110(1): 23-47. 
Pommier de Santi V. Dia, A., Adde, A., Hyvert, G., Galant, J., Mazevet, M., Nguyen, C., Vezenegho, S.B., Dusfour, I., Girod, R., Briolant, S., 2016a. Malaria in French Guiana linked to illegal gold mining. Emer. Infect. Dis. 22, 344-346.

Pommier de Santi V. Girod, R., Mura, M., Dia, A., Briolant, S., Djossou, F., Dusfour, I., Mendibil, A., Simon, F., Deparis, X., Pagès, F., 2016b. Epidemiological and entomological studies of a malaria outbreak among French armed forces deployed at illegal gold mining sites reveal new aspects of the disease's transmission in French Guiana. Malar. J. 15, 35.

Pommier de Santi, V., Djossou, F., Barthes N., Bogreau, H., Hyvert, G., Nguyen, C., Pelleau, S., Legrand, E., Musset. L., Nacher, M., Briolant, S., 2016c. Malaria hyperendemicity and risk for artemisinin resistance among illegal gold miners, French Guiana. Emerging Infect. Dis. 22(5): 903-906.

Potter, A., Jardine, A., Neville, P.J. 2016. A survey of knowledge, attitudes, and practices in relation to mosquitoes and mosquito-borne disease in Western Australia. Front Public Health. 2016. 4:32.

Prakash, A, Mohapatra, P.K., Das, H.K., Sharma, R.K., Mahanta, J., 1998. Bancroftian filariasis in Namrup tea estate, district Dibrugarh, Assam. Indian J Public Health. 42(4):103-7, 112.

Rahman, W.A., Che'Rus, A., Ahmad, A.H., 1997. Malaria and Anopheles mosquitos in Malaysia. Southeast Asian J. Trop. Med. Public Health. 28(3): 599-605.

Rawlings, P., Curtis, C.F., 1982. Tests for the existence of genetic variability in the tendency of Anopheles culicifacies species B to rest in houses and to bite man. Bull. World Health Org., 60 (3): 427 $-432$.

Recht, J., Siqueira A., Monteiro, W., Herrera, S.M., Herrera, S., Lacerda, M., 2017. Malaria in Brazil, Colombia, Peru and Venezuela: current challenges in malaria control and elimination. Malar. J. 16(1): 273.

Richards, P., VanWey, D., 2015. Where deforestation leads to urbanization: how resource extraction is leading to urban growth in the Brazilian Amazon. Ann. Assoc. Am. Geogr. 105(4): 806-823.

Rodrigures, M. S., Batista E. P., Silva, A. A., Costa, F. M., Neto, V. A., Gil, L. H., 2017. Change in Anopheles richness and composition in response to artificial flooding during the creation of the Jirau hydroelectric dam in Porto Velho, Brazil. Malar. J. 16: 87.

Rosa-Freitas, M.G., Broomfield, G., Priestman, A., Milligan, P.J., Momen, H., Molyneux, D.H., 1992. Cuticular hydrocarbons, isoenzymes and behavior of three populations of Anopheles darlingi from Brazil. J. Am. Mosq. Control Assoc. 8(4) 357-366.

Rubio-Palis, Y., Bevilacqua, M., Medina, D.A., Moreno, J.E., Cárdenas, L., Sánchez, V., Estrada, Y., Anaya, W., Martínez, Á., 2013. Malaria entomological risk factors in relation to land cover in the Lower Caura River Basin, Venezuela. Mem. Inst. Oswaldo Cruz. 108(2):220-8. 
Russell, B., Muir, L., Weinstein, P., Kay B., 1996. Surveillance of the mosquito Aedes aegypti and its biocontrol with the copepod Mesocyclops aspericornis in Australian wells and gold mines. Med. Vet. Entomol. 10: 155-160.

Russell, P., Rao, T., 1942. On the ecology of larvae of Anopheles culicifacies Giles, in borrow-pits. Bull. Entomol. Res. 32(4): 341-361.

Saha S, Pattanayak, S., Sills, E. Singha, A., 2011. Under-mining health: environmental justice and mining in India. Health Place, 17: 140-148.

Sahu, S.S., Gunasekaran, K., Krishnamoorthy, N., Vanamail, P., Mathivanan, A., Manonmani, A., Jambulingam, P. 2017. Bionomics of Anopheles fluviatilis and Anopheles culicifacies (Diptera: Culicidae) in relation to malaria transmission in East-Central India. J. Med. Entomol. 54(4): 821-830.

Sallum, M.A.M., Peyton, E.L., Wilkerson, R.C., 2005. Six new species of the Anopheles leucosphyrus group, reinterpretation of An. elegans and vector implications. Med. Vet. Entomol. 19:158-199.

Samson, D.M., Archer, R.S., Alimi, T.O., Arheart, K.L., Impoinvil, D.E., Oscar, R., Fuller, D.O., Qualls, W.A., 2015. New baseline environmental assessment of mosquito ecology in northern Haiti during increased urbanization. J. Vector. Ecol. 40(1):46-5.

Sanchez, J.F., Carnero, A.M., Rivera, E., Rosales, L.A., Baldeviano, G.C., Asencios, J.L., Edgel, K.A., Vinetz J.M. and Lescano, A., 2017. Unstable malaria transmission in the southern Peruvian Amazon and its association with gold mining, Madre de Dios, 2001-2012. Am. J. Trop. Med. Hyg 96(2): 304-311.

Sang, R., Kioko, E., Lutomiah, J., Warigia, M., Ochieng, C., O'Guinn, M., Lee, J.S., Koka, H., Godsey, M., Hoel, D., Hanafi, H., Miller, B., Schnabel, D., Breiman, R.F., Richardson, J., 2010. Rift Valley fever virus epidemic in Kenya, 2006/2007: the entomologic investigations. Am. J. Trop. Med. Hyg. 83 (2): 28-37.

Santos, V., Yokoo, E., Souza-Santos, R., Atanaka-Santos, M., 2009. Socioenvironmental factors associated with the spatial distribution of malaria in the Vale do Amanhecer settlement, Municipality of Juruena, State of Mato Grosso, 2005. Rev. Soc. Bras. Med. Trop. 42, 47-53.

Schmidt, K.A., Ostfeld, R.S., 2001. Biodiversity and the dilution effect in disease ecology. Ecology. 82: 609-619.

Sheela, A.M., Ghermandi, A., Vineetha, P., Sheeja, R.V., Justus, J., Ajayakrishna, K. 2017. Assessment of relation of land use characteristics with vector-borne diseases in tropical areas. Land Use Policy. 93 : 369-380.

Shiff, C., 2002. Integrated approach to malaria control. Clin. Microbiol. Rev. 15(2): 278-293.

Silbergeld, E. K., Nash, D. Trevant, C. Strickland, G. T. Souza J. M. Silva R.S.U., 2002. Mercury exposure and malaria prevalence among gold miners in Pará, Brazil. Rev. Soc. Bras. Med. Trop. 35(5): 421-429. 
Singhanetra-Renard, A., 1993. Malaria and mobility in Thailand. Soc. Sci. Med. 37(9): 1147-1154.

Sinka, M.E., Bangs, M.J., Manguin, S., Rubio-Palis. Y., Chareonviriyaphap, T., Coetzee, M., Mbogo, C.M., Hemingway, J., Patil, A.P., Temperley, W.H., Gething, P.W., Kabaria, C.W., Burkot, T.R., Harbach, R.E., Hay, S.I., 2012. A global map of dominant malaria vectors. Parasit Vectors. 5:69.

Sinka, M.E., Bangs, M.J. Manguin, S. Chareonviriyaphap, T., Patil, A.P., Temperley, W.H., Gething, P.W., Elyazar, I.R., Kabaria, C.W., Harbach, R.E., Hay, S.I., 2011. The dominant Anopheles vectors of human malaria in the Asia-Pacific region: occurrence data, distribution maps and bionomic précis. Parasit. Vectors 4:89.

Sinka, M.E., Bangs, M.J., Manguin, S., Chareonviriyaphap, T., Patil, A.P., Temperley, W.H., Gething, P.W., Elyazar, I.R., Kabaria, C.W., Harbach, R.E., Hay, S.I., 2010. The dominant Anopheles vectors of human malaria in Africa, Europe and the Middle East: occurrence data, distribution maps and bionomic précis. Parasit. Vectors. 4: 89.

Soe, H.Z., Thi, A., Aye, N.N., 2017. Socioeconomic and behavioural determinants of malaria among the migrants in gold mining, rubber and oil palm plantation areas in Myanmar. Infect. Dis. Poverty. 6(1): 142.

Soleimani-Ahmadi, M., Vatandoost, H., Hanafi-Bojd, A.A., Zare, M., Safari, R., Mojahedi, A., Poorahmad-Garbandi, F., 2013. Environmental characteristics of anopheline mosquito larval habitats in a malaria endemic area in Iran. Asian. Pac. J. Trop. Med. 6(7): 510-515.

Steiger, D.B.M., Ritchie, S.A., Laurance, S.G.W., 2016. Mosquito communities and disease risk influenced by land use change and seasonality in the Australian tropics. Parasit Vectors. 9: 387.

Surendran, S.N., Ramasamy, M.S., De Silva B. G. D. N. K., Ramasamy, R., 2006. Anopheles culicifacies sibling species $B$ and $E$ in Sri Lanka differ in longevity and in their susceptibility to malaria parasite infection and common insecticides. Med. Vet. Entomol. 20; 153-156.

Surendran, S.N., Jude, P.J., Weerarathne, T.C., Parakrama Karunaratne, S.H., Ramasamy, R., 2012. Variations in susceptibility to common insecticides and resistance mechanisms among morphologically identified sibling species of the malaria vector Anopheles subpictus in Sri Lanka. Parasit Vectors. 2012; 5: 34.

Sylla, M., Bosio, C., Urdaneta-Marquez, L., Ndiaye, M., Black, W.C., 2009. Gene flow, subspecies composition, and dengue virus-2 susceptibility among Aedes aegypti collections in Senegal. PLoS Negl. Trop. Dis. 3(4): e408.

Tauil, P. L., 1986. Comments on the epidemiology and control of malaria in Brazil. Mem. Inst. Oswaldo Cruz, 81: (suppl II): 39-41. 
Tucker Lima, J.M., Vittor, A., Rifai, S., Valle, D., 2017. Does deforestation promote or inhibit malaria transmission in the Amazon? A systematic literature review and critical appraisal of current evidence. Philos. Trans. R. Soc. Lond. B Biol. Sci. 372(1722): 20160125.

Turell, M.J., 2012. Members of the Culex pipiens complex as vectors of viruses. J. Am. Mosq. Control Assoc. 28(4 Suppl):123-6.

Tusting, L.S., Ippolito, M.P., Willey, B.A., Kleinschmidt, I., Dorsey, G., Gosling, R.D. Lindsay, S.W., 2015. The evidence for improving housing to reduce malaria: a systematic review and meta-analysis. Malar J. 14: 209.

Tusting, L.S., Willey, B., Lines, J., 2016. Building malaria out: improving health in the home. Malar. J. 15: 320.

Tusting, L., Bottomley, C., Gibson, H., Kleinschmidt, I., Tatem, A. Lindsay S. Gething P., 2017. Housing improvements and malaria risk in sub-Saharan Africa: A multi-country analysis of survey data. PLoS Med. 14(2): e1002234.

Yahner, R.H., Morrell, T.E., Rachael, J.S., 1989. Effects of Edge Contrast on Depredation of Artifical Avian Nests. The Journal of wildlife management. 53(4): 1136-1138.

van der Meide, W., de Vries, H., Pratlong, F., van der Wal, A., Sabajo, L., 2008. Epidemiology of cutaneous leishmaniasis in Suriname: A study performed in 2006. Emerging. Inf. Dis. 6(5): 857-859.

Veeken, H., 1993. Malaria and gold fever. Brit. Med. J. 307(6901): 433-434.

Verdrager, J., 1986. Epidemiology of the emergence and spread of drug-resistant falciparum malaria in South-East Asia and Australasia. J. Trop. Med. Hyg. 1986 Dec;89(6): 277-289.

Vij, D. Urbanization and solid waste management in India: Present practices and future challenges. Procedia - Social Behavioral Sciences. 37: 437-447.

Vittor, A.Y., Gilman R.H., Tielsch, J., Glass, G., Shields, T., Lozano, W. S., Pinedo-Cancino, V. Patz, J.A., 2006. The effect of deforestation on the human-biting rate of Anopheles darlingi, the primary vector of Falciparum malaria in the Peruvian Amazon. Am. J. Trop. Med. Hyg. 74(1):3-11.

Vittor, A. Y., Pan, W., Gilman, R. H., Tielsch J., Glass, G., Shields, T., Sánchez-Lozano, W., Pinedo, V., Salas-Cobos, E., Flores, S., Patz, J.A., 2009. Linking deforestation to malaria in the Amazon: Characterization of the breeding habitat of the principal malaria vector, Anopheles darlingi. Am. J. Trop. Med. Hyg. 81: 5-12.

Wangroongsarb, P., Satimai, W. Khamsiriwatchara, A. Thwing, J. Eliades, J. Kaewkungwal J. C. Delacollette, C., 2011. Respondent-driven sampling on the Thailand-Cambodia border. II. Knowledge, perception, practice and treatment-seeking behaviour of migrants in malaria endemic zones. Malar J. 9(10): 117. 
1165

1166

1167

1168

1169

1170

1171

1172

1173

1174

1175

1176

1177

1178

1179

1180

1181

1182

1183

1184

1185

1186

1187

1188

1189

1190

1191

1192

1193

1194

1195

1196

1197

1198

1199

1200

1201

1202

1203

1204

1205

1206

1207

Weetman, D., Kamgang, B., Badolo, A., Moyes, C.L., Shearer, F.M., Coulibaly, M., Pinto, J., Lambrechts, L., McCall, P.J., 2018. Aedes mosquitoes and Aedes-borne arboviruses in Africa: current and future threats. Int. J. Environ. Res. Public Health. 15(2).

Wijesundere, D.A., Ramasamy, R., 2017. Analysis of historical trends and recent elimination of malaria from Sri Lanka and its applicability for malaria control in other countries. Front Public Health. 5:212.

Wilson, A., Dhiman, R., Kitron, U., Scott, T., van den Berg H., Lindsay S., 2014. Benefit of insecticidetreated nets, curtains and screening on vector borne diseases, excluding malaria: A systematic review and meta-analysis. PLoS Negl. Trop. Dis. 8(10): e3228.

Wilson M.L., Elisha R., Roncoli C., Agyei-Baffour P., Tenkorang E.Y., 2015. Integrated assessment of artisanal and small-scale gold mining in Ghana-Part 3: Social sciences and economics. Int. J. Environ. Res. Public Health. 12:8133-8156.

Wongsrichanalai, C., Sirichaisinthop, J., Karwacki, J., Congpuong, K., Miller, R., Pang L., Thimasarn, K., (2001). Drug resistant malaria on the Thai-Myanmar and Thai-Cambodian borders. Southeast Asian J. Trop. Med. Public Health 32(1): 41-49.

World Bank, 2002. Mining and development. Global mining: Treasure or trouble? Mining in developing countries. Washington, D.C.

World Health Organization, 2010. Malaria in the Greater Mekong Subregion: Regional and country profiles. India.

World Health Organization, 2017. Malaria-Free Sri Lanka. New Delhi, India. http://apps.searo.who.int/PDS_DOCS/B5395.pdf

Yapabandara, A.M.G.M., Curtis, C. F., 2004. Vectors and malaria transmission in a gem mining area in Sri Lanka. J. Vect. Ecol. 29(2): 264-276.

Yapabandara, A.M.G.M., Curtis, C.F. Wickramasinghe M.B. Fernando W.P., 2001. Control of malaria vectors with the insect growth regulator pyriproxyfen in a gem-mining area in Sri Lanka. Acta Tropica 80: $265-276$.

Yasuoka, J. and Levins, R., 2007. Impact of deforestation and agricultural development on anopheline ecology and malaria epidemiology. Am. J. Trop. Med. Hyg. 76(3): 450-460.

Young, K.I., Mundis, S., Widen, S.G., Wood, T.G., Tesh, R.B., Cardosa, J., Vasilakis, N., Perera, D., Hanley, K.A., 2017. Abundance and distribution of sylvatic dengue virus vectors in three different land cover types in Sarawak, Malaysian Borneo. Parasit Vectors. 10(1): 406. 

changes on the abundance, distribution, and host-seeking behavior of Aedes arbovirus vectors in oil palm-dominated landscapes, southeastern Côte d'Ivoire. PLoS One. 12(12): e0189082.

1211

1212 